\title{
Effect of Export Expansion Grant on the Growth of Nigeria's Non-Oil Export
}

\author{
Maji Ali ${ }^{1 *} \quad$ Stella Ifeoma Madueme ${ }^{2}$ \\ 1.Department of Economics, Kogi State College of Education, Ankpa-Nigeria \\ 2.Department of Economics, University of Nigeria, Nsukka-Nigeria
}

\begin{abstract}
This study examines the effects of Export Expansion Grant (EEG) on the growth of Nigeria's non-oil export. EEG scheme was introduced in 1986 at a time the government of Nigeria was focussing on diversifying her economy. Thus this paper attempt to analyse the effects of EEG on non-oil exports from $1986-2015$. The study used data set of non-oil export as the dependent variable while EEG, foreign income, gross fixed capital formation and real exchange rate were used as independent variables. Of these variables, growth in non-oil exports, growth in foreign income were stationary at levels. The rest variables were stationary at first difference. The study therefore employed Auto Regressive Distributed lag Model (ARDL) technique due to the mix I(O) and I(I). The paper concludes that EEG has no significant effects on Nigeria's non-oil exports. The paper recommends extending EEG to producers of domestic products that are yet to be exported. Also, government should diversify activities in the agriculture sector to further export in livestock, horticulture, floriculture, wildlife preservation among others to strengthen diversification agenda in Nigeria.
\end{abstract}

Keywords: Non-oil Exports promotion, Export Expansion Grant, Diversification of Nigeria's Economy

DOI: $10.7176 / \mathrm{JESD} / 10-22-06$

Publication date: November $30^{\text {th }} 2019$

\section{Introduction}

Since the beginning of the $21^{\text {st }}$ century, there has been a considerable call for export diversification in most developing countries, as well as, expanding their source of foreign earning. According to Mishra (2013), proponents of export diversification argues that export promotion through policies such as export subsidies will increase economic growth. The shift to export promotion became necessary when some Latin American countries that previously adopted the Import Substitution Strategy (ISS) or inward-oriented strategy before mid-1970s began to experience debt crises and low Gross Domestic Product (GDP) growth rate which subsequently led to imbalance of payment crises (Kruegar, 1997). The new thinking was particularly anchored by multilateral institutions such as the World Bank and International Monetary Fund and strongly encouraged developing countries to embark on liberal trade reforms in order to open up their economies to international trade (Edwards, 1993).

Fadehunsi (1986), Udah (2012) and Usman (2010), among others, believed that expansion and promotion of the export sector of the economy is an important determinant factor for economic growth through its dynamic effect on the rest of the economy. The core of these views according to Edward (1993) is that export expansion yields positive externalities that spread on the non-export sectors of the economy. Apart from the increase in the overall total productivity of the economy, export expansion will enhance employment generation and, subsequently, reduces social cost of unemployment on the government. Also, Usman and Salami (2008) opined that the continuous inflow of foreign earnings from export is a sure way for improving the balance of payments position of the economy. According to them, the export expansion programme of the Asian Tigers that inspired growth was made possible not because of the forces of demand and supply alone but a product of carefully stateplanned intervention that provided an array of incentives that encouraged export growth. That is why Jafee (1985) said that the success stories recorded by these emerging economies were tied to their trade openness and improvement in their export trade.

Despite openness of Nigerian economy, international terms of trade is yet to improve because the dominant product of international trade constitutes mainly of non-renewable resources (Udah, 2012). It became necessary therefore that diversification of the economy should be a prerequisite to accelerate and sustain economic growth of Nigeria. In recognition of this, successive governments in Nigeria made attempts to put in place several programmes and initiated trade policies among which was the establishment of the Nigerian Export Promotion Council (NEPC) of 1976 to ensure steady growth of non-oil exports. This initiative became even more strengthened in the 1980s when many developing countries began to experience economic recession that led to large and growing internal and external imbalances in the economy. According to Okoh (2004) the drive for nonoil products became necessary because of the volatile nature of the international oil market and exhaustible nature of crude oil as a natural resource. Also, Ezike and Ogege (2012) observed that Nigeria's over-dependence on oil and the type of macroeconomic policies pursued by the government was responsible for turning the terms of trade against non-oil products which constituted the mainstay of Nigeria's economy prior the year 1970s. This affirmed CBN (2000) which reported that in 1970 the percentage share of non-oil in total earnings declined steadily from 
$97.2 \%$ in 1960 at independence to $42.4 \%$ in $1970,3.9 \%$ in 1980 and $2.7 \%$ in 1984 . This development eroded the international competitiveness of Nigeria's non-oil goods and their exportability. It became evident that Nigeria needs to diversify her export base not only to hedge against oil volatility shock but also as a means of increasing export earnings as a means of improving balance of payment. This can only be achieved effectively through the revitalization and promotion of non-oil exports.

It is in realization of this that government of Nigerian made non-oil export promotion a key element of its Structural Adjustment Programme (SAP) in 1986 as recommended by World Bank and International Monetary Fund (Bright, 2010). Since then government of Nigeria through the NEPC has adopted several financial and nonfinancial incentives to induce non-oil export in Nigeria, among which is the Export Expansion Grant (EEG) designed to encourage meaningful diversification of the economy. According to NEPC (2008), the objectives of EEG are to encourage companies of non-oil to engage in export business rather than domestic business; promote the development of non-oil products and diversification of Nigeria's export trade; and assist in promoting the development of export related industries in Nigeria. All these objectives are designed to enable EEG attract both potential domestic exporters and foreign investors to further production of non-oil product for export.

According to Nwidobie (2014), incentives provided through banks for non-oil production in Nigeria have grown from $\$ 100.2$ million in 1980 to $\$ 749$.1 million in 1991 , $\$ 25.3074$ billion in 2000 and increased sharply to N241.5billion in 2009 (Nwidobie, 2014). It is pertinent to know that providing incentives for exports is not peculiar to Nigeria alone. It is noted that governments all over the world provide all manners of support and incentives in order to expand their non-oil exports in a competitive global market. However, the worry of this paper is that despite the huge amount invested in EEG, the economy of Nigeria is yet to be diversified as expected and as a result the poverty and unemployment level continue to worsen each passing year. It is therefore important to examine the effectiveness of EEG on Nigeria's non-oil exports expansion drive. To achieve the objective of this study, the rest of the paper is divided as follows.

\section{Theoretical Literature}

Export promotion has become an activity of growing importance in both developed and developing countries. Today more countries are fast realizing that export promotion provides a lot of avenues for growth and means of survival in an increasingly competitive and international economic environment. According to Feeder (1983), export promotion strategy is usually considered by countries aspiring for rapid economic growth. However, because many exporters lack the motivation, resource to exploit foreign market opportunities, national government and other public organization have initiated programs of support and assistance to boost export trade. In this study therefore, export promotion entails export financing and non-financial strategies that will stimulate output from a domestically focused business model to one that is outward-oriented and export base.

It is obvious to say that export promotion is indispensable for overcoming disequilibrium in the balance of payments. It is in recognition of this that Nyong (2005) argues that a deficit in a nation's balance of payment can be adjusted through export promotion strategy. According to World Bank (1984) and UNTACD (1989), promoting exports will afford developing countries to correct imbalances in their external sector and at the same time ensure full recovery of their domestic economies. Equally, Helpman and Krugman(1985), Todaro and Smith(2003) and Sarbapriya (2011) observes that a thriving export provide significant source of foreign exchange earnings which can be used to divert production towards the most- growth enhancing industries. This in turn alleviates the shortage of foreign exchange which is a common problem that affects developing countries today. This agrees with Esfahani (1991) who stresses that exports possess the potentials to ease pressure on the balance of payment, provide greater access to international market and generate employment opportunities and increase welfare. In addition, expansion of the export sector leads to widespread productivity growth in the economy.

Further review of trade literature in respect of EEG and its impact on the growth of non-oil, have shown that export promotion is an inevitable policy framework for a long-term growth. Vohra (2001) showed the relationship between non-oil export incentives and economic growth in India, Pakistan, Philippines, Malaysia and Thailand for the period 1973 to 1993 . The empirical results indicated that when a country has achieved some level of economic development then exports have a positive and significant impact on economic growth. The study also showed the importance of liberal market policies by pursuing export expansion driven strategies.

Recent time series studies that have attempted to use economic methodology of co-integration for developing countries have not been able to establish without doubt that a robust relationship exists between export promotion and economic growth in the Long-run, that is, the variables are co-integrated (Omra and Gadda, 2015). Mah (2005) studied the long-run causality between exports and economic growth for China using error correction term. The study reveals that export expansion is insufficient to explain the patterns of real economic growth.

The attempt at finding out the extent to which Nigerian export strategies have been effective in diversifying the productive base of Nigeria led Onayemi and Ishola (2009) into revealing that non-oil export have performed below expectation under export promotion policy. This outcome supports the argument by Sabasat (2002) that export promotion does not have any significant impact on economic growth of low income countries. Also, Akeem 
(2011) did a study on the performance evaluation of foreign trade on economic growth in Nigeria $(1970$ - 2005). He found that $91 \%$ increase in export will cause economic growth to decrease by $19 \%$. He therefore recommended that conscious efforts be made by the government to fine tune the various macroeconomic variables in order to provide an enabling environment to promote export trade. However, Ezike, Ikpesu and Amah (2012) empirically studied the macroeconomic impact of trade on the growth of Nigeria's economy. They found that export and foreign direct investment inflows were positive and are significant determinants of economic growth of Nigeria. They suggested that Nigeria needs to diversify its export base away from oil and add value to its exports by emphasizing on non-oil production and exportation. They further recommended that primary products should be processed into semi-finished and finished industrial products before they are exported.

\subsection{An Overview of Nigeria's non-oil export promotion Policy}

Giving the volatility nature of oil in Nigeria, governmental realized the need to expand and promote non-oil sector to stimulate growth became imperative. As a result of this successive government in Nigeria initiated various macroeconomic policies over the years with a view to achieve growth especially in the non-oil exports through support incentives to encourage diversification of the economy. Supportive policies for achieving this objective could be categorized into the protectionist policy (1960-1985), trade liberalization policy (SAP Era of 1986-1998) and the export promotion policy (Post SAP Era of 1999 to date) in the history of export promotion strategy in Nigeria.

\subsection{The protectionist policy (1960 - 1985),}

According to Oyejide (1986), the period 1960-1985 witnessed government pursuing Import-Substitution Industrialization (ISI) policy as a way of increasing growth. According to Oyejide (1986), the ISI policy aims at expanding the domestic industrial base, encouraging farmers to expand their farms and increase the production and exports of cash crops. Trade policy within this period had protectionism policy as a core framework. Specific policy recommendations within this period includes: removal of agricultural exports taxes and sales tax to promote agricultural sectors, placement of high tariffs on agricultural imports, issuance of import license and quantitative restrictions and use of direct control policies like exchange rate control. The ultimate goal being to protect domestic industries that were set up to produce import substitute goods. This period witnessed the establishment of Nigerian Export Promotion Council in 1976, making non-oil promotion and diversification of the economy a national policy objective in Nigeria for the first time. The primary objective of the council is the promotion of non-oil exports and development of export oriented industries in Nigeria.

\subsection{Trade liberalisation Policy (1986-1998 - SAP Era).}

From the mid-1980s foreign exchange earnings accruing from crude oil exports began to fall which made import of capital inputs difficult for Nigeria. Thus in the period 1986-1988, which is also known as the SAP era, trade policies were liberalized in order to achieve greater openness to integration with the world economy. It is for this reason and the need for greater non-oil exports promotion that government in 1986 adopted export-oriented development strategy as a major cornerstone of the economy. Major trade policy trust in the Nigerian trade liberalization policy of 1986 - 1998 includes the introduction of Structural Adjustment programme in order to revitalize the non-oil sectors. This encourages intensive use of local material resources and a more liberal foreign exchange allocation regime, abolition of commodity marketing Board in 1986. The Board was scrapped to allow farmers and/or private exporters of agricultural tradables, direct access to the international market so that they could derive the full benefits of international trade. Others include establishment of the right of exporter to retain the proceeds of their exports in domiciliary account. Government also established Export Development Fund (EDF) and Export Expansion Fund (EEF) to provide various range of incentives to exporters of semi-manufactured and manufactured products; and Creation of three Export Promotion Zones with zonal offices in Lagos, Kano and Port Harcourt and creation of four commercial desks in London, New York, Abidjan and Jedda among others. The overall aim is to promote non-oil export in Nigeria.

\subsection{Export Promotion Policy (Post SAP Era, 1999 - Date).}

The period 1999-date could be regarded as the era of export promotion policy (Post SAP Era) in Nigeria. Since 1999 government at several times intensified support to Small and Medium Enterprises (SMEs) in order to enhance export of their products (both at raw materials and finished product levels). Okoh (2004) noted that government's non-oil exports promotion policies during this era was aimed at enhancing industrialization and diversification of the economy through policy support to SMEs to enhance the export of their products (Adesoji and Sotubo ,2013). Trade promotion policies since 1999 include; the abolition of export licensing, strengthening of the current retention scheme to enable exporters hold proceeds in foreign currency in their banks, granting of tax relief on export earned by banks on export credit in order to encourage banks to finance export by reducing their tax burden and offering of export credit guarantee and Insurance scheme to assists banks to bear the risks in export business 
and in effect facilitates export financing and export volumes.

\section{Data source and Methodology}

To meet the core objective of the study, that is examining the effect of EEG on the growth of non-oil export in Nigeria using annual quarterly data for the period 1986-2015. In this study, the variables of interest include nonoil exports (as key variables), foreign income, real exchange rate, gross fixed capital formation, population and export expansion grant as intervening variables. All the necessary data for the sampled period are obtained from Central Bank of Nigeria (CBN) statistical bulletin, and World Development Indicators. All the variables are taken in their natural logarithms to avoid problem of heteroscedasticity.

Non-oil Export Growth Model for this study is expressed in the form

$\mathrm{NOX}=\mathrm{f}(\mathrm{FY}, \mathrm{GFCF}, \mathrm{RER}, \mathrm{EEG})$

Where:

NOX= Aggregate Nigeria's Non-oil Export Growth

$\mathrm{FY}=$ Foreign income which is represented by OECD output

GFCF $=$ Gross Fixed Capital Formation (which is a proxy for capital).

$\mathrm{RER}=$ Real Exchange rate (this is measured by the annual value of domestic currency (naira) relative to the foreign currency (dollars).

EEG = Export Expansion Grant (proxied by the credit to the private sector interacted with total non-oil export)

The ARDL equation based on the above functional relation is

$$
\begin{aligned}
& \Delta \operatorname{lnNOX}=\alpha_{0}+\sum_{j=1}^{p} \alpha_{1} \Delta \operatorname{lnf} y_{t-j}+\sum_{j=1}^{p} \alpha_{2} \Delta \operatorname{lngfcf_{t-j}}+\sum_{j=1}^{p} \alpha_{3} \Delta r e r_{t-j}+\sum_{j=1}^{p} \alpha_{4} \Delta \operatorname{lneeg_{t-j}}+\alpha_{5} \ln f y_{t-i} \\
& +\alpha_{6} \operatorname{lng} f c f_{t-i}+\alpha_{7} r e r_{t-i}+\alpha_{8} \operatorname{lneeg}_{t-i}+u_{t}
\end{aligned}
$$

Equation 2 states that Nigeria's non-oil export growth is determined by Foreign Income (FY) which is represented by OECD output, Gross Fixed Capital Formation, Real Exchange Rate, Export Expansion Grant (which is index of export grants for each year) and other random factors (Ut). Due to the empirical nature of this study, real exchange rate (RER) rather than the nominal exchange rate (NER) becomes more relevant (Abogan, Akinola and Baruwa 2014).

In this study we are concerned about the relationship between structural composition of non-oil exports growth and the effect of EEG on them. Theoretically, it is expected that EEG (which is index of export grants for each year) will have positive effect on the non-oil export. This is because increase in EEG is expected to promote the performance of the non-oil sector. Exchange rate is expected to have negative effect on non-oil exports as increase in the exchange rate will discourage investment in the export potentials of the non-oil sector. On the other hand, an appreciation of the exchange rate would result in the cost of imported materials/inputs which will, therefore, discourage export potentials of the non-oil sector.The short run version of the equation is specified as:

$$
\begin{aligned}
& \Delta \operatorname{lnNOX}=\alpha_{0}+\sum_{j=1}^{p} \alpha_{1} \Delta \operatorname{lnfy} y_{t-j}+\sum_{j=1}^{p} \alpha_{2} \Delta \operatorname{lngfcf_{t-j}}+\sum_{j=1}^{p} \alpha_{3} \Delta r e r_{t-j}+\sum_{j=1}^{p} \alpha_{4} \Delta \operatorname{lneeg}_{t-j}+\alpha_{5} \Delta E C T_{t-1} \\
& +v_{t} \ldots
\end{aligned}
$$

Where $\Delta$ represents the first difference operator, $\mathrm{ECM}_{\mathrm{t}-1}$ is the error correction term and $\mathrm{Vt}$ is a disturbance term. The Error Correction Model (ECM) utilizes information in the error term of the long-run model to approximate deviation from the equilibrium and represent the short run necessary to move the system backward toward its equilibrium.

\section{Presentation of Data}

The software statistics used for this work is summarized and tabulated in table 1. 
Table 1: Descriptive Statistics of the variables used in the study

\begin{tabular}{clllll}
\hline Variables & Obs & Mean & Std. Dev. & Min & Max \\
eeg & 117 & 5907112 & 8374870 & 48974.84 & $2.69 \mathrm{e}+07$ \\
nox & 117 & 2577.254 & 3141.091 & 5.6218 & 1011.52 \\
oilexp & 117 & 5179.359 & 5817.262 & 9.2824 & 17366.75 \\
fy & 117 & 29900000000000 & 12100000000000 & 11.7 & 49300000000000 \\
gfcf & 117 & 2630000000000 & 4320000000000 & 11400000000 & 14100000000000 \\
rer & 117 & 53.44781 & 68.2912 & 0.013339 & 241.5361 \\
top & 117 & 0.000000000163 & 0.000000000141 & 0.000000000000873 & 0.000000000451 \\
pcgdp & 117 & 249557 & 73024.77 & 173011.9 & 385227.6 \\
ry & 117 & 33600000000000 & 17100000000000 & 15200000000000 & 69800000000000 \\
lnry & 117 & 31.02626 & 0.4822187 & 30.35512 & 31.87638 \\
lngfcf & 117 & 26.85914 & 2.110611 & 23.15261 & 30.27806 \\
lneeg & 117 & 14.25358 & 1.937483 & 10.79906 & 17.10872 \\
lnfy & 117 & 30.25481 & 4.540211 & 2.459589 & 31.52933 \\
lnnox & 117 & 6.591135 & 2.031162 & 1.726652 & 9.211492 \\
\hline
\end{tabular}

Source: Author's Computation, 2018

\subsection{Result For Unit Root}

Having given a brief summary of the series used as in above, they are respectively tested for stationarity. The test results are produced and presented in table 2;

Table 2 : Summary Result of Unit Root Test for all Series

\begin{tabular}{|c|c|c|c|c|c|}
\hline \multirow{2}{*}{ Variable } & \multicolumn{2}{|c|}{ Levels } & \multicolumn{2}{|c|}{ First Diff } & Order \\
\hline & Test Stat & $5 \%$ Crit. Val. & Test Stat & $5 \%$ Crit. Val. & Integration \\
\hline lneeg & -2.150 & -2.889 & -5274 & -2.889 & $\mathrm{I}(1)$ \\
\hline lnnox & -4.468 & -2.889 & NA & NA & $\mathrm{I}(0)$ \\
\hline $\ln f y$ & -4.932 & -2.889 & NA & NA & $\mathrm{I}(0)$ \\
\hline $\ln g f c f$ & -0.885 & -2.889 & -4.634 & -2.889 & $\mathrm{I}(1)$ \\
\hline rer & 6.374 & -2.889 & -2.915 & -2.889 & $\mathrm{I}(1)$ \\
\hline $\ln p c g d p$ & 1.815 & -2.889 & -4.094 & -2.889 & $\mathrm{I}(1)$ \\
\hline $\ln r y$ & 2.500 & -2.889 & -4.109 & -2.889 & $\mathrm{I}(1)$ \\
\hline
\end{tabular}

\section{Source: Authors' computation 2018}

NA denotes Not Applicable

From the table 2, it can be observed that all the series used are stationary at first difference [i.e. I(1)]. However, Innnox, lnoilexp and lnfy variables are stationary in levels [i.e. I(0)]. This means that of the quarterly data from the time period of 1986 to 2015, save for quarterly growth in non-oil exports and growth in foreign income, the other variables are not reliable for immediate use in forecasting as their potency to forecast the lost past or unknown future is crippled. It would further mean that for these series to be used, further pre-estimation tests need be conducted to ascertain the most appropriate time series technique. The test to be conducted for the model would be the test for cointegration. Autoregressive and Distributed Lag model was adopted for the model since the variables are mix of $\mathrm{I}(1)$ and $\mathrm{I}(0)$.

\subsection{RESULT FOR COINTEGRATION- BOUNDS TEST}

To evaluate if there exists a long run relationship among the variables in our model, the Bound Test (BT) approach under the instrumentality of the F-statistics was adopted. The table 3 show a summary of the cointegration bounds test approach. 
Table 3: Bounds Test Result

\begin{tabular}{lll} 
Test Statistic & Value & K \\
F-Statistic & 4.518239 & 4 \\
\hline Critical Value Bounds & & \\
\hline Significance & I0 Bound & I1 Bound \\
$10 \%$ & 2.45 & 3.52 \\
$5 \%$ & 2.86 & 4.01 \\
$2.5 \%$ & 3.25 & 4.49 \\
$1 \%$ & 3.74 & 5.06 \\
\hline
\end{tabular}

Source: Authors' computation, 2018

Since the test statistic $(\mathrm{F}$-statistic $=4.518239)$ is greater than the upper bounds at $5 \%$ level of significance [i.e. $F-$ statistic $=4.518239>4.01$ ], and thus conclude that long-run relationship exists in the model. This test verifies if there exists a long run relationship amongst the relating variables of interest.

\subsection{ESTIMATION AND INTERPRETATION OF RESULTS}

The ARDL model having been confirmed to possess long-run relationship is presented in summary in the table 4 . Table 4: Model Estimation Result (Long-run)

Dependent Variable: Innox

\begin{tabular}{ccccc} 
Variable & Coefficient & Std Error & t-statistic & Prob \\
constant & $-28.784346^{*}$ & 2.837704 & -10.143533 & 0.0000 \\
lnfy & $-0.046933^{* * *}$ & 0.025191 & -1.863066 & 0.0656 \\
lngfcf & $1.438547^{*}$ & 0.146803 & 9.799154 & 0.0000 \\
rer & $-0.018011^{*}$ & 0.002651 & -6.794243 & 0.0000 \\
lneeg & -0.047914 & 0.089658 & -0.534414 & 0.5943 \\
\hline
\end{tabular}

Source: Authors' computation, 2018

Note: $\quad *$ denotes significance at $1 \%$

** denotes significance at $5 \%$

$* * *$ denotes significance at $10 \%$

From table 4, it could be observed that growth in foreign income proxied by the OECD output significantly reduces the growth in the non-oil exports of Nigeria. This could be due to substitutability of Nigerian non-oil exports for same from other countries. The estimation reveals that $1 \%$ point increase in foreign income would reduce non-oil export by about $0.047 \%$ point. This finding is reliable at a $10 \%$ level of doubt. Growth in capital which is proxied by the growth in the Gross Fixed Capital Formation would significantly increase the growth in non-oil exports in Nigeria. The finding was found to be significant at the $1 \%$ level of significance. Real Exchange rate is found to also have a significant influence on the growth in non-oil exports in Nigeria. Increases in the Real Exchange of Naira for Dollar would cause the non-oil exports to fall. This reveals that depreciation (or devaluation for fixed exchange rate regimes) of the Nigerian currency would spur growth in non-oil exports. This estimation is found to be significant at the 1\% level of significance, thus reliable. From the model, growth in Export Expansion Grants proxied by the interaction of loans to the non-oil sector and the total exports was found not to be significant on the growth in non-oil exports. Though a negative relationship was found explaining that as more grants came about given respective levels of exports, the growth in non-oil exports is expected to fall. The short-run estimation is presented below in the table 5 . 
Table 5: Model Estimation Result (Short-run)

Dependent Variable: lnnox

\begin{tabular}{ccccc} 
Variable & Coefficient & Std Error & t-statistic & Prob \\
$d($ lnnox $(-1))$ & $0.509143^{*}$ & 0.093688 & 5.435588 & 0.0000 \\
$d($ lnnox $(-2))$ & 0.033184 & 0.095055 & 0.349104 & 0.7278 \\
$d(\operatorname{lnfy})$ & -0.004162 & 0.003058 & -1.360733 & 0.1769 \\
$d(\operatorname{lnfy}(-1))$ & -0.000269 & 0.003769 & -0.071254 & 0.9433 \\
$d($ lnfy $(-2))$ & 0.005200 & 0.004628 & 1.123697 & 0.2640 \\
$d(\operatorname{lngff} f)$ & $0.589226^{*}$ & 0.198369 & 2.970352 & 0.0038 \\
$d(\operatorname{lngfcf}(-1))$ & -0.074850 & 0.377057 & -0.198510 & 0.8431 \\
$d(\operatorname{lngfff}(-2))$ & -0.254852 & 0.205270 & -1.241543 & 0.2175 \\
$d($ rer $)$ & $-0.009453^{* *}$ & 0.004517 & -2.092740 & 0.0391 \\
$d($ rer $(-1))$ & 0.001415 & 0.009149 & 0.154701 & 0.8774 \\
$d($ rer $(-2))$ & 0.003382 & 0.004464 & 0.757606 & 0.4506 \\
$d($ lneeg $)$ & $-0.176811^{*}$ & 0.051139 & -3.457455 & 0.0008 \\
$d($ lneeg $(-1))$ & 0.057544 & 0.091226 & 0.630787 & 0.5297 \\
$d($ lneeg $(-2))$ & -0.001874 & 0.054240 & -0.034542 & 0.9725 \\
CointEq $(-1)$ & $-0.180612^{*}$ & 0.041201 & -4.383694 & 0.0000 \\
\hline
\end{tabular}

Source: Authors' computation, 2018

Note: $*$ denotes significance at $1 \%$

** denotes significance at $5 \%$

$* * *$ denotes significance at $10 \%$

From table 5 it was estimated that it would take about $18.06 \%$ speed of adjustment for the short-run to converge into the long-run, thus for a sample size of 114 included observations, it would take the economy about 6 quarters to adjust to the long-run. This is about a period of 1 year 6 months. This finding is significant at the $1 \%$ level of significance, thus reliable.

\section{SUMMARY OF FINDINGS}

The study has dwelled on analysing the effect of Nigeria's export expansion grant on the growth of non-oil export using data from 1986-2015. The study utilised various economic indicators and found out that of the variables used for the model, growth in export expansion grant, growth in capital, real exchange rate and growth in per capita income were all found to be stationary at first difference, thus being integrated of order one [I(1)]. The growth in non-oil exports, and growth in foreign income were found to be stationary in levels. Given the composition of the models, the ARDL model was used to estimate and achieve the objective of the study.

The model was found to possess long-run relationship as estimated using the Bounds test of cointegration. From the model we found that foreign income was significantly a factor influencing growth in non-oil exports at $10 \%$ level of significance. Growth in capital and the real exchange rate were found to be significant at 5\% respectively. In terms of relationship direction, it was found that as the foreign income grew, Nigeria's non-oil export growth would fall. As the currency depreciated, the non-oil export growth is expected to rise, however, more capital signalled more non-oil exports. Export expansion grants significantly do not contribute to growth in non-oil exports. There was also strong evidence of convergence from short-run to long-run at a speed of adjustment of about $18.06 \%$ thus an estimated time of about 1 year 6 months for an observation of 114 quarters.

\section{CONCLUSION AND RECOMMENDATION}

The finding that foreign income growth would influence growth in Nigeria's non-oil export negatively would have implication on the rest of the world - the advanced world especially, since the OECD output proxied this - would produce commodities which would push Nigeria's non-oil exports out of the market. Higher income could translate to improved technology, more economies of scale and increased ability to incur more costs. This could crowd out Nigerian non-oil exports. Growth in capital is seen to influence non-oil exports positively. This implies that as capital and its accumulation increase, Nigeria has increased propensity to create new commodities which are not oil-related. This would also mean that the marginal productivity of capital is still positive, thus there is still room for expansion in the non-oil industry. The real exchange rate measures the value of goods across borders, unlike the nominal exchange rate which explains the price of foreign currency. A unit fall in real exchange rate would mean the Naira loses value - depreciates. This is expected from the model to cause an increase in non-oil exports. An implication of this finding is that fall in the real exchange rate would encourage foreign patronage since it would make commodities sold in Nigeria cheaper compared to their prices outside the shores of the country. Then the EEG was found to influence non-oil exports negatively and insignificantly too. This would imply that the 
amount devoted to export expansion is not optimal to spur non-oil exports. There also could be possibility that the export expansion has over the years been focused on the oil sector which could cause its insignificance in the nonoil sector. Thus, considering the findings of this study we recommend the following;

1. Export expansion grant in Nigeria so far do not seem to reflect on the growth in per capita income. For the grant to be effective, it should be people oriented. This can be achieved by allotting a certain percentage of EEG to producers of domestic consumption. This would enable producers of domestic products ability to save costs and improve the quality of their commodities to expand to meet domestic demand. On a long-run this will ensure a faster rate of conversion from local to international consumption and hence foster increase in both personal and national income which is sure to reflect in the per capita income of the country.

2. The agricultural sector already has programmes to tackle prominent issues of improved seeds, fertilization and mechanization. However, little has been done in terms of livestock agriculture, horticulture, floriculture and wildlife preservation. These are grey areas the government needs to revisit and consider extending EEG to so as to boost exports of them for a more diversified economy.

3. Oil is today the dominant sector in Nigeria; as a result investments, grants and aids have been heavily concentrated in this sector. This study strongly recommends that there should be diversification in Nigeria's export expansion grants to spur reformation and innovations/ inventions in the traditional and manufacturing sector.

4. The agricultural and manufacturing sectors should be prioritised in the allocation of grants for export promotion activities. This would enable the production in these sectors cheaper and competitive for exports in the international market.

\section{References}

Adesoji, A. A. \& Sotubo, O.D. (2013). Non-oil Exports in the Economic Growth of Nigeria: A Study of Agricultural and Mineral Resources. Journal of Educational and Social Research 3(2), 1 - 40.

Akeem, U. O. (2008). Non-oil Exports Determinant and Economic Growth in Nigeria. European Journal of Business and Management 3(3): 1- 23.

Bright, C. O. (2010). Nigerian Firms' Non-oil Export Improvement: An Econometric Transformation Paradigm. European Journal of Scientific Research 40(4), 547 - 556.

CBN (2000). The Structure of Nigerian Economy and Implications of Development. Lagos: Ream Communications Ltd. Pp 198 - 199.

Edward, S. (1993). Openness, Productivity and Growth: What Do We Really Know? Economic Journal 108 (447): $383-398$

Esfahani, H. S. (1991). Export, Imports and Economic Growth in Semi-Industrialized Countries Journal of Development Economics. 35: 93 - 116.

Ezeudu, I. J. (2014). Evaluation of non-oil contribution in export financing development of Nigeria's Economy: An Empirical Analysis of Export Processing Zone. Research Journal of Finance and Accounting 5(6): 58-63.

Ezike, J. E., Ikpesu, F. \& Amah, P. (2012). Macroeconomic Impact of Trade on Nigerian Growth: An Empirical Evaluation. Research Journal of Business Management and Accounting 1 (4), 79 - 83.

Ezike, J.E. \& Ogege, S. (2012). Nigerian Foreign Trade Policy: Its Impact on Non-oil Exports. Journal of Economics and International Finance 4(8): 192 - 200.

Fadehunsi, A. (1986). Export Promotion as a Strategy for Industrialization. Being a paper presented at a workshop on Export Promotion, Kano.

Feeder, G. (1983). On Export and Economic Growth. Journal of Development Economics 12: 59 - 74.

Helpman, E. \& Krugman, P. R. (1985). Market Structure and Foreign Trade: Increasing Returns, Imperfect Competition and International Economy. Cambridge: MA MII Press.

Kruegar, A. (1978). Trade Policy and Economic Development: How we Learn. The American Economic Review $87(1): 1-22$.

Krugman, P. R. \& Obstfeld, M. (2003). International Economics: Theory and Policy $6^{\text {th }}$ Eds. Cambridge: Cambridge University Press.

Mah, J. S. (2005). Export Expansion, Economic Growth and Causality in China. Applied Economics Letters. 12

Mishra, P. K. (2013). The Dynamics of Relationship between Exports and Economic Growth in India. International Journal of Economics Sciences and Applied Research. 4(2): -70

NEPC(2008).Non-oil Export Promotion. Retrieved from www.epcng.com/nonoilexports/default.asp on $14 / 02 / 2017$

Nwidobie, B.M. (2014). Growth in Nigeria's Non-oil Export Finance and Non-oil Export Performance: A Correlation Analysis. Retrieved from www.worldbank.org on 21/3/2016.

Okoh, R. N. (2004). Global Integration and the Growth of Nigeria's Non-Oil exports. Paper Presented at the 
African Conference. Oxford, UK.

Omran, S. S. S. \& A. M. Gradda (2015). Some Economics Determinants of Non-Oil Exports in Sudan: An Empirical Investigation (1990 - 2012) Journal of Business Studies Quarterly 7 (1), 125 - 150.

Onayemi, S. O. \& Ishola, R. A. (2009). Diversifying the Productive Base of Nigeria: An Economic Approach to the Assessment of Non-oil Export Promotion Strategies. Retrieved from: www.Nigerianbestforum/blog? $\mathrm{P}=44659: 6-7$

Sabasat, T. (2002). Does Export Promotion Increase Economic Growth? Some Cross Section Evidence, Development Policies Review, 20: 7 - 13.

Sarbapriya, R. (2011). A Causality Analysis on the Empirical Nexus between Export and Economic Growth: Evidence from India. International Affairs and Global Strategy 1: 24 - 39 retrieved on 9/11/2014 from www.iiste.org.

Todaro, P. \& Smith, S. C. (2003).Economic Development $8^{\text {th }}$ ed. Singapore: Addison Wesley.

Udah, E. B. (2012). Export-Growth Hypothesis: An Econometric Analysis of the Nigerian Case. Interdisciplinary Journal of Research in Business 2(4): 39 - 49.

UNCTAD (1989). Trade Policy Reform and Export Performance in Developing Countries in the 1980s in Trade and Development Report 1989, Geneva.

Usman, D. \& Salami, A. (2008). The Contribution of Nigerian Export-Import (NEXIM). Bank Towards Export Export of Non-oil Growth in Nigeria. International Business Management Review 2(3), 85 - 90.

Usman, D. (2010). Non - Oil Export Determinants and Economic Growth in Nigeria 1985 - 2008. European Journal of Business and Management Sciences 3(3): 124 - 132.Vohra, R. (2001). Export and Economic Growth: Further Time Series Evidence from Less Developed Countries. International Advances in Economic Research 7 (3): 345 - 350.

World Bank (1984). Towards Sustained Development in Sub-Saharan Africa. Washington DC. The World Bank. 